\title{
DNA Sequence Homology between the Terminal Inverted Repeats of Shope Fibroma Virus and an Endogenous Cellular Plasmid Species
}

\author{
CHRIS UPTON AND GRANT MCFADDEN* \\ Department of Biochemistry, University of Alberta, Edmonton, Canada T6G $2 \mathrm{H} 7$
}

Received 26 August 1985/Accepted 18 October 1985

\begin{abstract}
DNA hybridization experiments indicate that the genome of a tumorigenic poxvirus, Shope fibroma virus (SFV), possesses sequence homology with DNA isolated from uninfected rabbit cells. Southern blotting experiments, either with high-complexity rabbit DNA as probe and SFV restriction fragments as targets or with high-specific activity, ${ }^{32} \mathrm{P}$-labeled, cloned SFV sequences as probes and rabbit DNA as target, indicate that the homologous sequences map at two locations within the viral genome, one in each copy of the terminal inverted repeat sequences. Unexpectedly, Southern blots revealed that the homologous host sequences reside in a rabbit extrachromosomal DNA element. This autonomous low-molecular-weight DNA species could be specifically amplified by cycloheximide treatment and was shown by isopycnic centrifugation in cesium chloride-ethidium bromide to consist predominantly of covalently closed circular DNA molecules. DNA sequencing of pSIC-9, a cloned 1.9-kilobase fragment of the rabbit plasmid species, indicated extensive homology at the nucleotide level over a 1.5-kilobase stretch of the viral terminal inverted repeat. Analysis of open reading frames in both the plasmid and SFV DNA revealed that (i) the $\mathrm{N}$-terminal 157-amino acid sequence of a potential 514-amino acid SFV polypeptide is identical to the $\mathrm{N}$-terminal 157 amino acids of one pSIC-9 open reading frame, and (ii) a second long pSIC-9 open reading frame of 361 amino acids, although significantly diverged from the comparable nucleotide sequence in the virus, possessed considerable homology to a family of cellular protease inhibitors, including $\alpha 1$-antichymotrypsin, $\alpha 1$-antitrypsin, and antithrombin III. The potential role of such cellular plasmid-like DNA species as a mediator in the exchange of genetic information between the host cell and a cytoplasmically replicating poxvirus is discussed.
\end{abstract}

Certain members of the poxvirus family have been known for many years to be the etiologic agents for a variety of tumors found in the wild $(2,28,34)$. Unlike other DNA tumor viruses, the poxvirus genome replicates within virosomes or "factories" in the cytoplasm of infected cells, and it is believed to encode all or most of the enzymes required for its own replication. Thus, poxviruses are less dependent upon host cell functions than are any other animal virus group (for reviews, see references 10, 18, 25, 25a, and 43).

Shope fibroma virus (SFV), a member of the genus leporipoxvirus, is of special interest as a prototype of the tumorigenic poxviruses because it grows well in tissue culture, induces characteristic fibromas in rabbits and is amenable to analysis at the molecular level $(15,34)$. The physical map of the viral DNA has recently been deduced, and the complete genomic library in plasmid vectors is available $(7,11,42)$. The SFV genome is 160 kilobases $(\mathrm{kb})$ in size (11) and has a coding capacity for in excess of 100 proteins. It is of particular interest that different strains of SFV vary in tumorigenicity and that isolates can spontaneously lose their oncogenic potential without loss of infectivity (15), implying that the genetic information governing tumor induction is highly variable. This is strikingly reminiscent of observations with regard to members of the orthopoxvirus genus, such as vaccinia virus, in which spontaneous DNA rearrangements occur with high frequency at or near the terminal inverted repeat sequences (TIR) of the

\footnotetext{
* Corresponding author.
}

viral genome $(1,13,14,24,26)$, and suggests that a relatively small region of the SFV genome may be responsible for the tumorigenic potential of this virus.

Reports that the genomes of several herpesviruses (herpes simplex virus types 1 and 2, Epstein-Barr virus, cytomegalovirus) contain sequences homologous to mammalian cell DNA $(27,29,30)$ prompted us to ask whether SFV DNA possesses detectable homology with host rabbit DNA and, if so, whether these sequences might also be implicated in the tumorigenicity of this virus. Although poxvirus morphogenesis is believed to be entirely cytoplasmic, and the mechanism by which a poxvirus could capture host genomic DNA is unclear, recent evidence that the thymidine kinase and a 19,000-molecular-weight protein of vaccinia virus share significant amino acid sequence homology with chicken thymidine kinase (22) and transforming growth factor $\alpha(5,6)$, respectively, suggests that an exchange of genetic information between host and poxviruses is possible. Here we report that SFV possesses demonstrable DNA sequence homology with an endogenous cellular plasmid species and suggest that small polydisperse circular (spc) DNA molecules may potentially function as intermediates for the exchange of genetic information between poxviruses and their host cells.

\section{MATERIALS AND METHODS}

Cells and viruses. SFV (strain Kasza) was obtained from the American Type Culture Collection. The SIRC cell line (American Type Culture Collection) and primary rabbit 


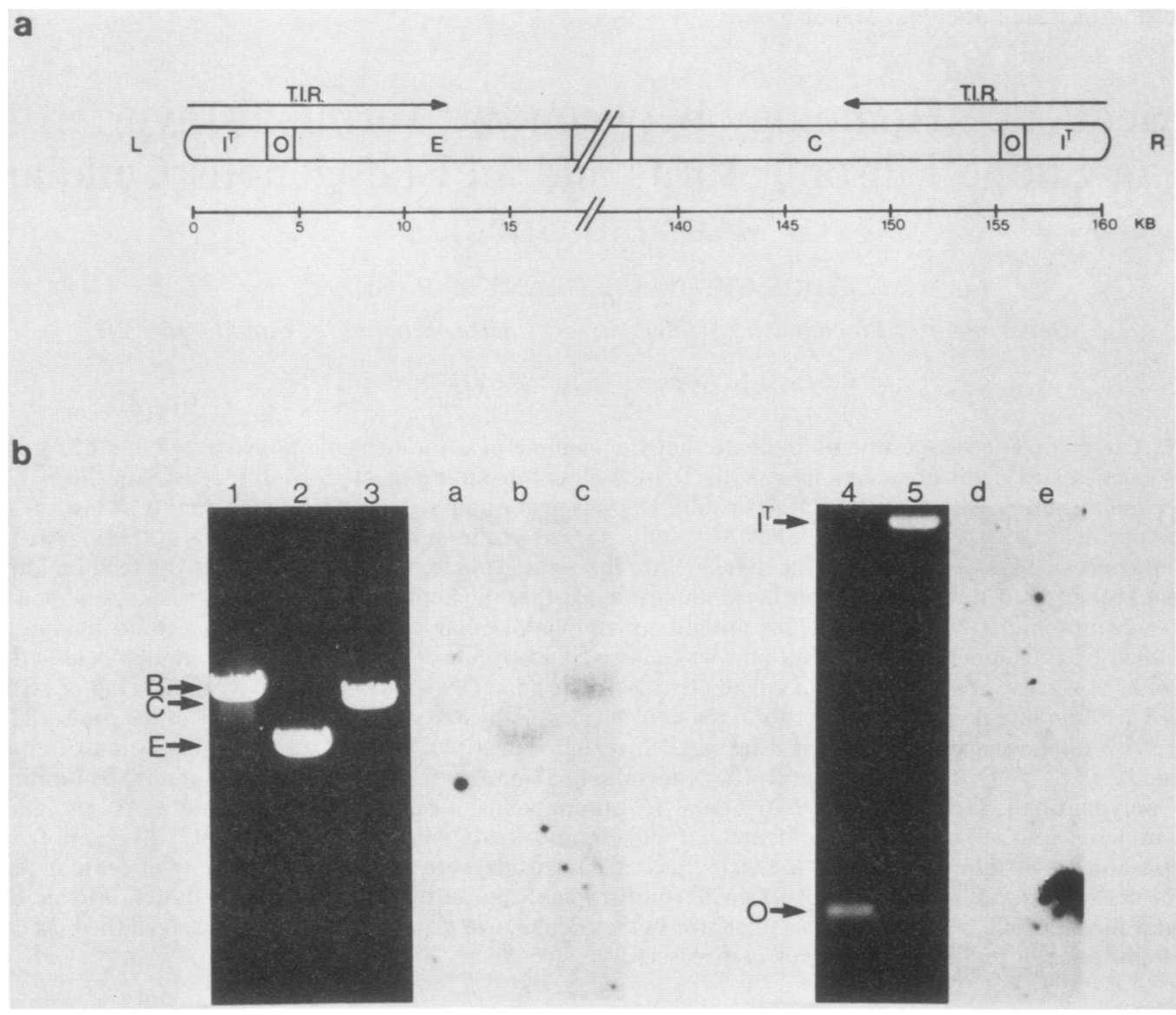

FIG. 1. Hybridization of total rabbit DNA probe to cloned BamHI fragments of SFV DNA. (a) Abbreviated BamHI restriction map of the SFV genome (11). (b) Lanes 1 through 5 contain $100 \mathrm{ng}$ of purified cloned SFV BamHI restriction fragments B, C, E, O and $\mathrm{I}^{\mathrm{T}}$, respectively, per kb, electrophoresed in $\mathbf{0 . 7 \%}$ agarose. Fragment B maps in the center of the SFV genome and is included here as a high-molecular-weight negative control. Lanes a through e are the corresponding nitrocellulose blots probed with total rabbit DNA by using a modified Southern procedure (see Materials and Methods). All other SFV BamHI fragments tested (not shown) gave negative results.

kidney fibroblasts (Flow Laboratories) were grown in Dulbecco minimal Eagle medium supplemented with $10 \%$ fetal calf serum.

Electrophoresis, blotting and hybridization. Conditions of restriction enzyme digestions, agarose gel electrophoresis, nick translation, and standard Southern blotting have been described $(11,42)$. To probe cloned viral DNA fragments with total high-complexity rabbit DNA, a modified Southern blot procedure was used: calf thymus DNA was omitted from the prehybridization and hybridization solutions by adjusting these to contain $50 \%$ formamide, $7 \times$ Denhardt solution, $2 \times \mathrm{SSC}(1 \times \mathrm{SSC}$ is $0.15 \mathrm{M} \mathrm{NaCl}$ plus $0.015 \mathrm{M}$ sodium citrate), and $0.35 \%$ sodium dodecyl sulfate (27). Hybridization with a total of $1.2 \times 10^{8} \mathrm{cpm}$ of ${ }^{32} \mathrm{P}$-labeled rabbit DNA probe was done at $42^{\circ} \mathrm{C}$ for $40 \mathrm{~h}$, and washing was performed in $0.1 \times \mathrm{SSC}-0.1 \%$ sodium dodecyl sulfate at $50^{\circ} \mathrm{C}$.

Isolation of high-molecular weight DNA. Rabbit cells were suspended $\left(10^{7} / \mathrm{ml}\right)$ in $10 \mathrm{mM}$ Tris $(\mathrm{pH} 8.0)-1 \mathrm{mM}$ EDTA-pronase $(500 \mu \mathrm{g} / \mathrm{ml}$; Calbiochem-Behring Corp.)$0.5 \%$ sodium dodecyl sulfate, incubated at $37^{\circ} \mathrm{C}$ for $2 \mathrm{~h}$, and extracted three times with phenol-chloroform (1:1) and once with chloroform. Nucleic acid was precipitated with 2 volumes of alcohol, suspended in $10 \mathrm{mM}$ Tris ( $\mathrm{pH} \mathrm{8.0)}$ containing RNase $(50 \mu \mathrm{g} / \mathrm{ml})$, incubated at $50^{\circ} \mathrm{C}$ for $1 \mathrm{~h}$, extracted once with phenol-chloroform and once with chloroform, and then precipitated again with alcohol.

Hirt precipitation of high-molecular-weight DNA. The method of DNA isolation described above was followed except that, after incubation at $37^{\circ} \mathrm{C}$ for $2 \mathrm{~h}$, the solution was made $1.0 \mathrm{M} \mathrm{NaCl}$, left $16 \mathrm{~h}$ at $0^{\circ} \mathrm{C}$, and centrifuged at 15,000 rpm in a Sorvall SS-34 rotor to precipitate high-molecularweight DNA (17). The resultant supernatant was then treated as further described above.

DNA cloning and sequencing. Cloning and mapping of the relevant SFV restriction fragments in bacterial vectors have been described previously $(11,42)$. For cloning of the endogenous rabbit plasmid species, rabbit SIRC cells were pretreated for $16 \mathrm{~h}$ with cycloheximide $(50 \mu \mathrm{g} / \mathrm{ml})$, the Hirt supernatant was prepared as described above, and the DNA was fractionated by preparative agarose gel electrophoresis. The open circular (OC) and covalently closed circular (CCC) DNA species which hybridized to the SFV TIR probe (see Fig. 2) were excised, purified, digested with BamHI and cloned into the BamHI site of pUC8, with JM83 as the host (41). Recombinants were screened with the viral probe, and six positive clones were isolated. One clone, pSIC-9, contained a 1.9-kb insert and was used for sequence analysis. DNA sequencing was performed by using the Sanger dideoxy-chain termination method and exonuclease III- 


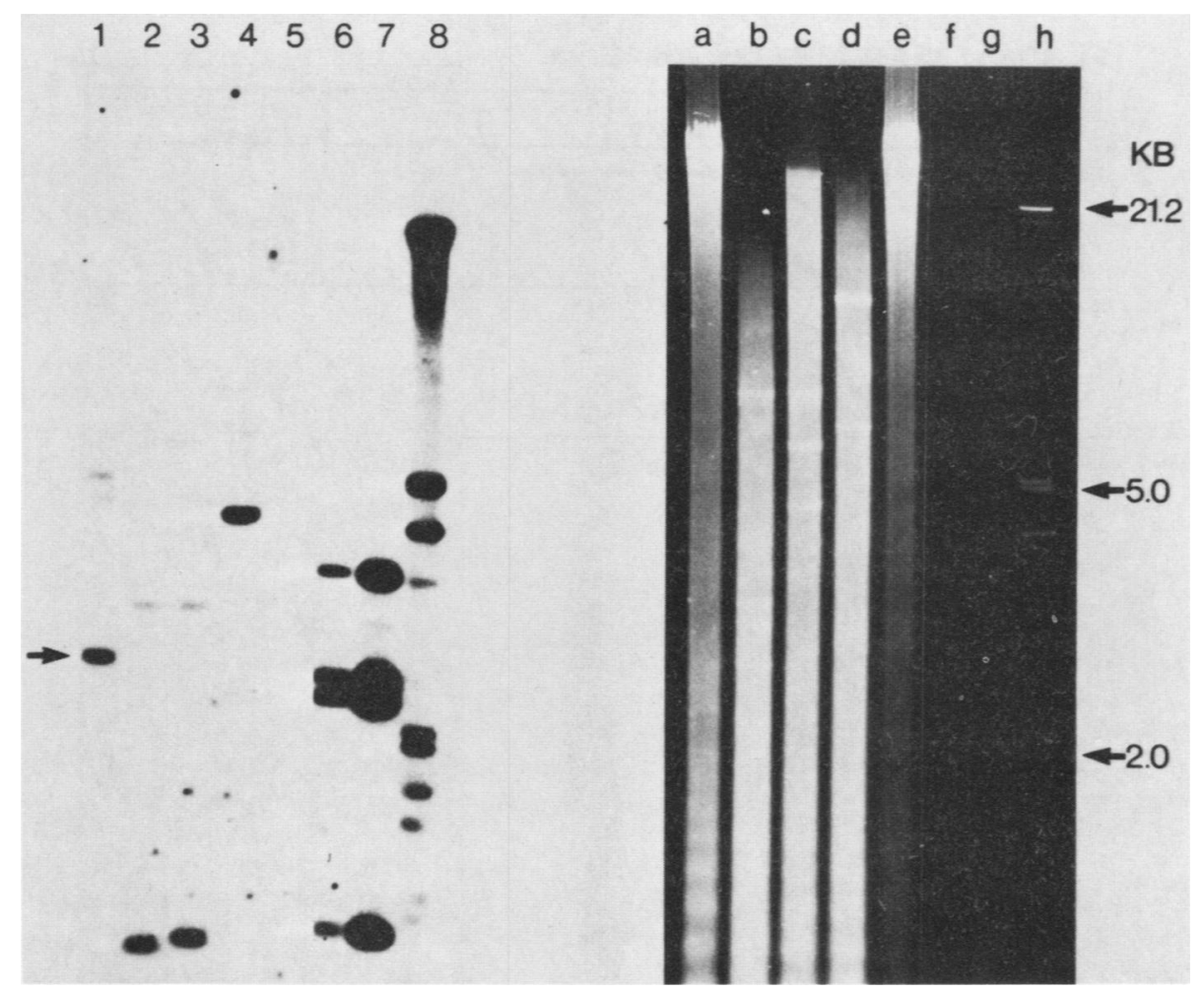

FIG. 2. Effect of cycloheximide treatment on rabbit plasmid copy number. Ethidium bromide-stained agarose gel (right panel, lanes a through $h$ ) of rabbit spc DNA and matching Southern blot (left panel, lanes 1 through 8) probed with $10^{7}$ cpm of SFV DNA (BamHI E fragment minus the $\mathrm{E}^{\mathrm{B}}$ subclone; See Fig. 3a) plus $5 \times 10^{5} \mathrm{cpm}$ of $\lambda$ probe for size markers. All samples were from rabbit SIRC cells and prepared by Hirt precipitation (17) to remove most of the high-molecular-weight chromosomal DNA. Cycloheximide treatment (lanes 1 through 4 and a through d) was $50 \mu \mathrm{g} / \mathrm{ml}$ for $16 \mathrm{~h}$ before harvest. Lanes 1 through 5 and a through e each contain $3 \mu \mathrm{g}$ of undigested DNA (lanes 1, 5, a, and e) or $3 \mu \mathrm{g}$ of DNA digested with AvaI plus EcoRI (lanes 2 and b), AvaI (lanes 3 and c), or EcoRI (lanes 4 and d). Lanes 6, 7, f, and g contain $10 \mathrm{pg}$ (lanes 6 and $\mathrm{f}$ ) and $100 \mathrm{pg}$ (lanes 7 and $\mathrm{g}$ ) of the $\mathrm{E}^{\mathrm{A}}, \mathrm{E}^{\mathrm{B}}, \mathrm{E}^{\mathrm{C}}, \mathrm{E}^{\mathrm{D}}$, and $\mathrm{E}^{\mathrm{E}}$ subclones of SFV BamHI E fragment (see the map in Fig. 3). Lanes 8 and h contain $50 \mathrm{ng}$ of $\lambda$ DNA digested with EcoRI plus HindIII. The arrow in the panel to the left refers to the major plasmid species (shown in Fig. 4 to be CCC DNA) detected in the undigested lanes.

generated unidirectional deletions as described previously $(16,31,41)$. Sequence manipulations and data base analysis were performed by using the core library programs of BIONET (IntelliGenetics, Inc.).

\section{RESULTS}

Detection of cross-hybridization between SFV and rabbit DNA. Although previous attempts to demonstrate DNA sequence homology between SFV and rabbit DNA were unsuccessful (19), the technologies then available limited investigators to the use of $\left[{ }^{3} \mathrm{H}\right] \mathrm{DNA}$ probes with relatively low specific activity. Thus, it seemed worthwhile to reevaluate the question by using cloned DNA in conjunction with $\left[{ }^{32} \mathrm{P}\right] \mathrm{DNA}$ probes of high specific activity. Our preliminary experiments were done by the method of Peden et al. (27), in which cloned viral DNA was exposed to high-complexity probe made from total rabbit DNA. Since the entire SFV genome had previously been cloned in bacterial plasmids (42) and mapped with respect to BamHI, BglI, HindIII, PstI, $P v u I I$, and $S s t$ I restriction sites (11), it was possible to work with these cloned SFV fragments and, thus, to avoid the use of viral DNA isolated from infectious poxvirus virions, which can be contaminated with very small amounts of host DNA (18). The results of such hybridization studies with the BamHI fragments of SFV DNA indicated that homology between viral and rabbit DNA could be detected and that only Bam HI fragments $\mathrm{C}$ and $\mathrm{E}$ hybridized to the rabbit DNA (Fig. 1). Examination of the BamHI restriction map (Fig. 1A) reveals that the fragments $C$ and $E$ are located at opposite ends of the SFV genome and span the junctions between the unique internal sequences and each copy of the TIR. The position of these fragments is such that they have $6 \mathrm{~kb}$ in common within the TIR and 7.0 and $11.6 \mathrm{~kb}$ of unique internal sequences for $\mathrm{E}$ and $\mathrm{C}$, respectively. The findings that only two fragments from the $160-\mathrm{kb}$ SFV genome hybridized to the total rabbit DNA probe and that these contained $6 \mathrm{~kb}$ of identical DNA sequence strongly suggested that the homology with rabbit DNA resides within the TIR sequences shared by fragments $\mathrm{C}$ and $\mathrm{E}$. Furthermore, this observation provided the impetus to use cloned viral TIR sequences as probes and total rabbit DNA as target. However, when purified BamHI E fragment of SFV was used to probe samples of genomic rabbit DNA by Southern blot analysis, the majority of host DNA which hybridized to the viral probe migrated as a low-molecular-weight species, even for undigested control DNA. Since the amount of this low-molecular-weight DNA was rather variable from sample to sample, two techniques were used to amplify the hybridization signal. (i) Cells were pretreated for $16 \mathrm{~h}$ with cycloheximide $(50 \mu \mathrm{g} / \mathrm{ml})$ before DNA extraction. Smith and Vinograd (35) found that this treatment increased the num- 


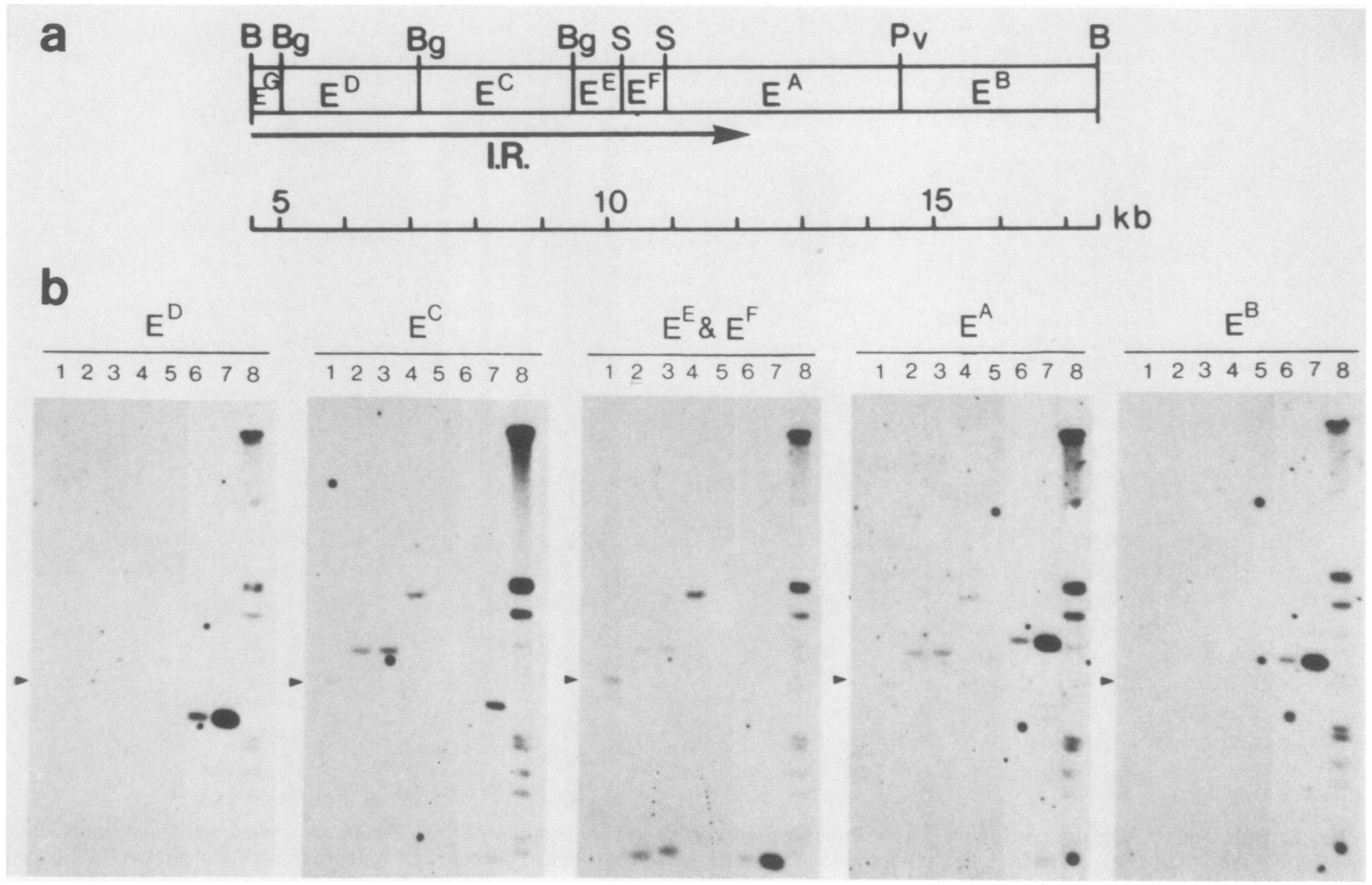

FIG. 3. Hybridization of SFV BamHI E fragment subclones to the rabbit plasmid species. (a) Restriction map of the subclones of SFV $B a m H I$ E fragment. The distance in kilobases from the left terminus of SFV and the extent of the inverted repeat of SFV (arrow) are also indicated. Abbreviations: B, BamHI; S, SmaI; Pv, PvuII. (b) Southern blots with subclones $E^{\mathrm{D}}, \mathrm{E}^{\mathrm{C}}, \mathrm{E}^{\mathrm{E}}$ plus $\mathrm{E}^{\mathrm{F}}, \mathrm{E}^{\mathrm{A}}$, and $\mathrm{E}^{\mathrm{B}}$ as probes. Arrowheads refer to the mobility of the undigested plasmid species indicated by the arrow in Fig. 2 . The DNA samples in lanes 1 through 8 are as described in the legend to Fig. 2.

ber of spc DNA molecules in eucaryotic cells by $20-$ to 30-fold. (ii) DNA was isolated from cells by the Hirt procedure (17) to precipitate most of the high-molecular-weight chromosomal DNA. Figure 2 demonstrates the effect of cycloheximide treatment on the amount of rabbit spc DNA present in Hirt supernatants which hybridizes to SFV DNA probe. The undigested DNA samples in lanes a and e of Fig. 2 were isolated by the Hirt procedure under identical conditions and with the same reagents except that the DNA in lane a was extracted from cells pretreated with cycloheximide. Although not visible in the photograph, faint bands were observed in lane 5 (untreated) of the original fluorogram at positions matching those seen in lane 1 (cycloheximidetreated DNA). Quantitation of the difference between these signals indicated that the cycloheximide treatment resulted in an approximately 50-fold amplification of this extrachromosomal DNA species without altering its apparent mobility. As will be shown further in the next section. the three bands in lane 1 of Fig. 2 represent the OC, linear, and CCC forms of the cellular extrachromosomal DNA elements. Digestion with a single-site restriction enzyme such as EcoRI (Fig. 2, lane 4) indicates the linearized plasmid size to be $4.8 \mathrm{~kb}$. Since the sum of the molecular sizes of fragments produced by some restriction enzymes, such as $A v a I$ (Fig. 2, lane 3), were often less than this, it can be concluded that only a fraction of the entire $4.8-\mathrm{kb}$ species is homologous to the viral TIR. These results together suggest that the host sequences homologous to SFV are present on an endogenous rabbit plasmid-like element with a low and variable copy number. Reconstitution blots indicate a maximum copy number of one to five per cell in cycloheximide-amplified cultures but less than one per cell in the established SIRC cell line.

Mapping of the DNA homologies and characterization of the rabbit plasmid species. To determine the size and position of the relevant homologous sequences within the SFV TIR, DNA isolated from Hirt supernatants of cells that had been pretreated with cycloheximide was then hybridized sequentially with purified subclones of SFV BamHI fragment E. These subclones of the SFV BamHI E fragment are diagrammed and oriented with respect to the SFV inverted repeat (Fig. 3a). Subclones $E^{D}$ and $E^{B}$ did not hybridize to the rabbit plasmid, whereas the contiguous $E^{C}$ and $E^{A}$, and $\mathrm{E}^{\mathrm{E}}$ plus $\mathrm{E}^{\mathrm{F}}$ subclones all gave positive hybridization signals (Fig. 3b). Control hybridizations with bacterial plasmid vector probes such as pBR322 failed to yield a signal (not shown). Digestion of the rabbit plasmid with AvaI (Fig. 3b, lane 3) produced two major fragments of 3.5 and $0.7 \mathrm{~kb}$, both of which still hybridized to the SFV BamHI-E probe but which could be distinguished by the fact that the $\mathrm{E}^{\mathrm{C}}$ and $\mathrm{E}^{\mathrm{A}}$ subclones only hybridized to the larger of these fragments, whereas the mixture of $\mathrm{E}^{\mathrm{E}}$ plus $\mathrm{E}^{\mathrm{F}}$ hybridized to both.

To demonstrate conclusively that the rabbit sequences homologous to SFV were present in the host cells as CCC 


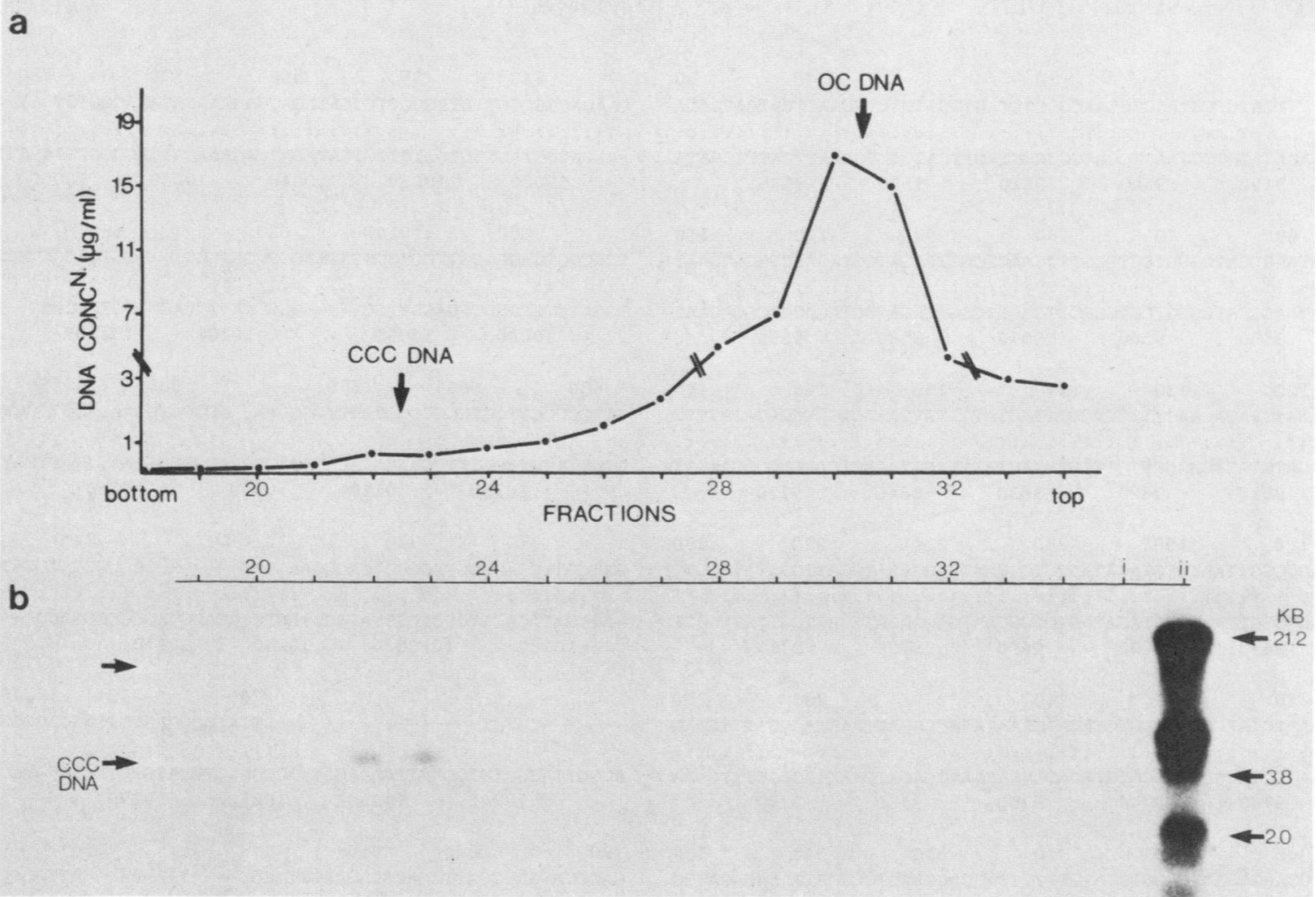

FIG. 4. Isopycnic centrifugation of rabbit plasmid DNA. (a) DNA ( $10 \mu \mathrm{g})$ from a Hirt supernatant of cycloheximide-treated $(50 \mu \mathrm{g} / \mathrm{ml}, 16$ h) primary rabbit kidney fibroblasts was subjected to isopycnic centrifugation in $5.0 \mathrm{M} \mathrm{CsCl}$ plus $250 \mu \mathrm{g}$ of ethidium bromide per ml. The gradient was fractionated, and the DNA concentration was determined by fluorimetry. (b) Aliquots of each fraction (undigested) were electrophoresed in $0.7 \%$ agarose, transferred to nitrocellulose, and probed with $5 \times 10^{6} \mathrm{cpm}$ of SFV BamHI E fragment plus $5 \times 10^{5} \mathrm{cpm}$ of $\lambda$ DNA. Lane i contains $10 \mathrm{pg}$ of the SFV BamHI E fragment digested with PvuII plus SmaI (Fig. 3). Lane ii contains $50 \mathrm{ng}$ of $\lambda$ DNA digested with EcoRI plus HindIII. Upper arrow refers to migration position of OC plasmid DNA which bands with rabbit chromosomal DNA (lanes 29,30 , and 31).

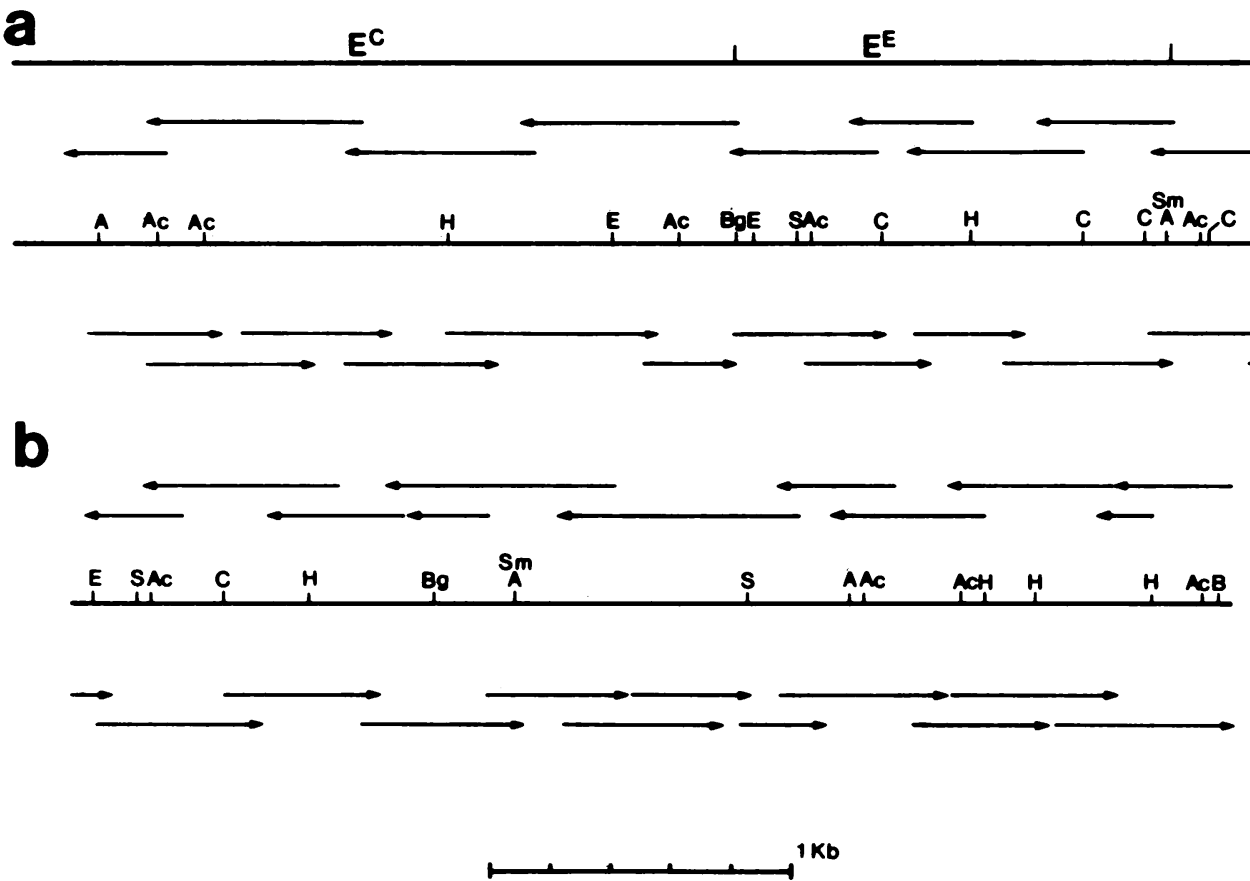

FIG. 5. Sequencing strategy for $2.5 \mathrm{~kb}$ of the SFV TIR and the cloned endogenous rabbit plasmid pSIC-9. DNA was cloned into appropriate M13 vectors, unidirectional deletions were constructed as described in Materials and Methods, and sequencing was performed by the Sanger dideoxy method (31). (a) SFV TIR between 8.4 and $10.9 \mathrm{~kb}$ from the termini. (b) The 1.9-kb insert from the cloned rabbit plasmid pSIC-9. Abbreviations: A, AvaI; Ac, AccI; B, BamHI; Bg, BglI; C, ClaI; E, EcoRI; H, HhaI; S, SstI; Sm, SmaI. 


\begin{tabular}{|c|c|c|c|c|c|}
\hline \multirow{2}{*}{\multicolumn{6}{|c|}{ 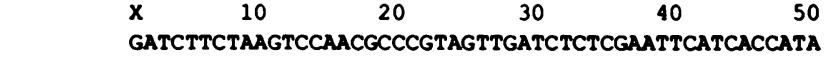 }} \\
\hline & & & & & \\
\hline \multicolumn{6}{|c|}{ : : : : : : : : : : : : : : : : : : : : : : : : : : : : : : : : : : : : : : : : : : : : : : : : : : : } \\
\hline \multicolumn{6}{|c|}{ ACCAGTAACAGATCTTCTAAGTCCAACGCCCGTAGTTGATCTCTCGAATTCATCACCATA } \\
\hline 9490 & 9500 & 9510 & 9520 & 95 & \\
\hline 60 & 70 & 80 & 90 & 100 & 110 \\
\hline \multicolumn{6}{|c|}{ CTGGGCATAAGCCATCGGGTCCTGCGTTTCAACTCGGTCAGATCGTAGAGCTCGGAGANT } \\
\hline \multirow{2}{*}{\multicolumn{6}{|c|}{ 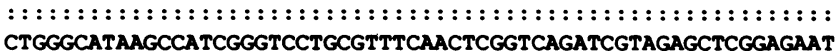 }} \\
\hline & & & & & \\
\hline 9550 & 9560 & 9570 & 9580 & & \\
\hline 120 & 130 & 140 & 150 & 160 & 170 \\
\hline \multicolumn{6}{|c|}{ TTAAACAGATGTATACAACTTTCTTCGTTTACTATTTTGTTAAACTCATGGGCACATTTT } \\
\hline \multirow{2}{*}{\multicolumn{6}{|c|}{ 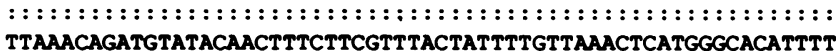 }} \\
\hline & & & & & \\
\hline 9610 & 9620 & 9630 & 9640 & & \\
\hline 180 & 190 & 200 & 210 & 220 & 230 \\
\hline \multicolumn{6}{|c|}{ TTAATCAGGGGGTTAATCTGTAGATAGTGTGCCAATGAGAAAATGGATTCGTTATTCCTT } \\
\hline \multirow{2}{*}{\multicolumn{6}{|c|}{ 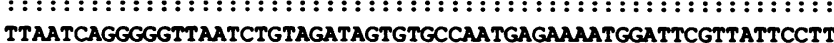 }} \\
\hline & & & & & \\
\hline 9670 & 9680 & 9690 & 9700 & & \\
\hline 240 & 250 & 260 & 270 & 280 & 290 \\
\hline
\end{tabular}

TTGTGTAATTCTATCGATTCCGTGTACATGTAATAAATCACATCAAATACGGTTTTGTAA

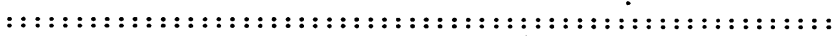
TTGTGTAATTCTATCGATTCCGTGTACATGTAATAAATCACATCAAATACGGTTTTGTAA $\begin{array}{lllll}9730 & 9740 & 9750 & 9760 & 9770\end{array}$

$\begin{array}{llllll}300 & 310 & 320 & 330 & 340 & 350\end{array}$
TCCGCCTCTAAGACAATCACGTCTATGTTTTTTTCTACGAAGTCCCCATTAAACAGACTG

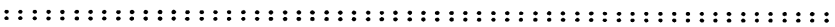
TCCGCCTCTAAGACAATCACGTCTATGTTTTTTTCTACGAAGTCCCCATTAAACAGACTG $\begin{array}{lllll}9790 & 9800 & 9810 & 9820 & 9830\end{array}$

$\begin{array}{llllll}360 & 370 & 380 & 390 & 400 & 410\end{array}$ TAGAAGTATTTGGAATACGCGGAGAGCACCAACCGATGCGCTCGGATGCTTTTGCCTTCC

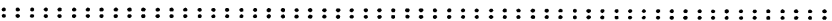
TAGAAGTATTTGGAATACGCGGAGAGCACCAACCGATGCGCTCGGATGCTTTTGCCTTCC $\begin{array}{lllll}9850 & 9860 & 9870 & 9880 & 9890\end{array}$

420 $430-440$ . GCGACGATTTCGACGTGCATAGTTTACCCTTCAAAAGAGTTTATACAAAGGATACGAC $\begin{array}{lllll}9910 & 9920 & 9930 & 9940 & 9950\end{array}$

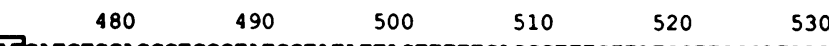
ATCATCTCGACCCTCCGTATCGTATATTACTTTTTCACCCTTTGTTATCGTTCCCATAAA

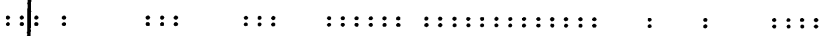
A]CGTT----CCCCGATTATAAGATATTATTTTTTCACCCTTTAACAGTCTCA--ATAAT $\begin{array}{lllll}9970 & 9980 & 9990 & 10000 & 10010\end{array}$

molecules, DNA present in the Hirt supernatant prepared from cycloheximide-treated primary rabbit kidney cells was subjected to isopycnic centrifugation in $\mathrm{CsCl}$ gradients containing ethidium bromide. Undigested DNA samples from each gradient fraction (Fig. 4a) were electrophoresed in an agarose gel, blotted, and probed with the BamHI E fragment of SFV DNA (Fig. 4b). Mitochondrial DNA and the rabbit plasmid banded at almost the same buoyant density in the $\mathrm{CsCl}$ gradient but were separated on the basis of their size during electrophoresis in agarose; note that mitochondrial DNA (17 kb) did not hybridize to the SFV probe (the mitochondrial DNA bands are visible on the stained gel in Fig. 2). The rabbit plasmid isolated from primary rabbit kidney cells (Fig. 4) was very similar to that detected in the SIRC cell line, and both displayed comparable homology to the SFV BamHI E fragment. In the original fluorogram, faint bands were also visible in fractions 29,30 , and 31 of the

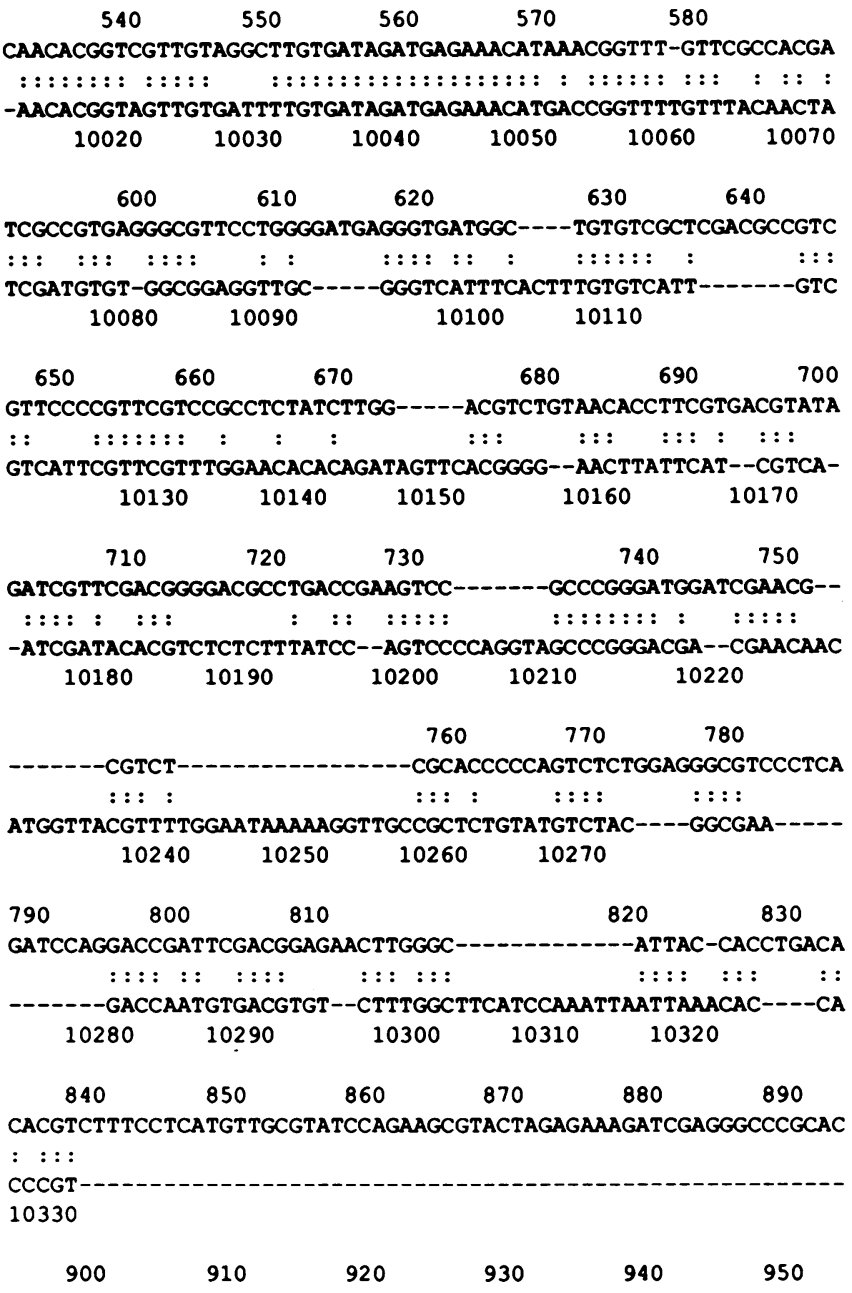

GATCTCTCCCAAGTCGTCCGGAACGACGAGCAACATGGCCGTTTGACGCCGTTTATACGG

$\begin{array}{llllll}960 & 970 & 980 & 990 & 1000 & 1010\end{array}$

gradient, corresponding to the OC form of the plasmid. Thus, we conclude that the bulk of the endogenous plasmid species detected by the SFV probe, at least in the case of the cycloheximide-amplified samples, exists as unnicked circles.

Cloning and DNA sequencing of the rabbit DNA plasmid. Two types of potential artifact could, in principle, account for the above observations. Firstly, in a recent report by Jones and Hyman (21), specious hybridization between herpes simplex virus DNA and human cellular DNA was shown to be caused by guanine-rich sequences which bind nonspecifically to pyrimidine-rich tracts on single-stranded DNA (40). Secondly, the possibility of low-level microbial plasmid contamination in the cultured cells or reagents (33) must be discounted. To rule these possibilities out, experiments to clone the endogenous rabbit plasmid sequences in pUC vectors were done. Control blots indicated that the rabbit plasmid could be linearized by several convenient 


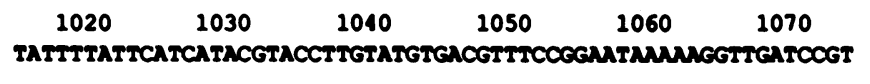

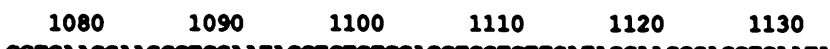

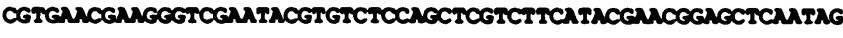

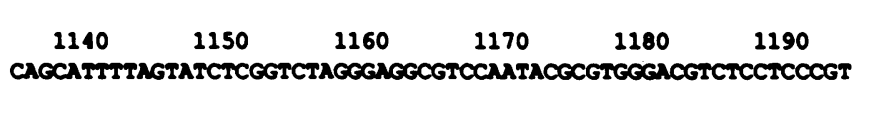

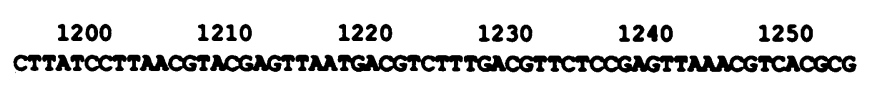

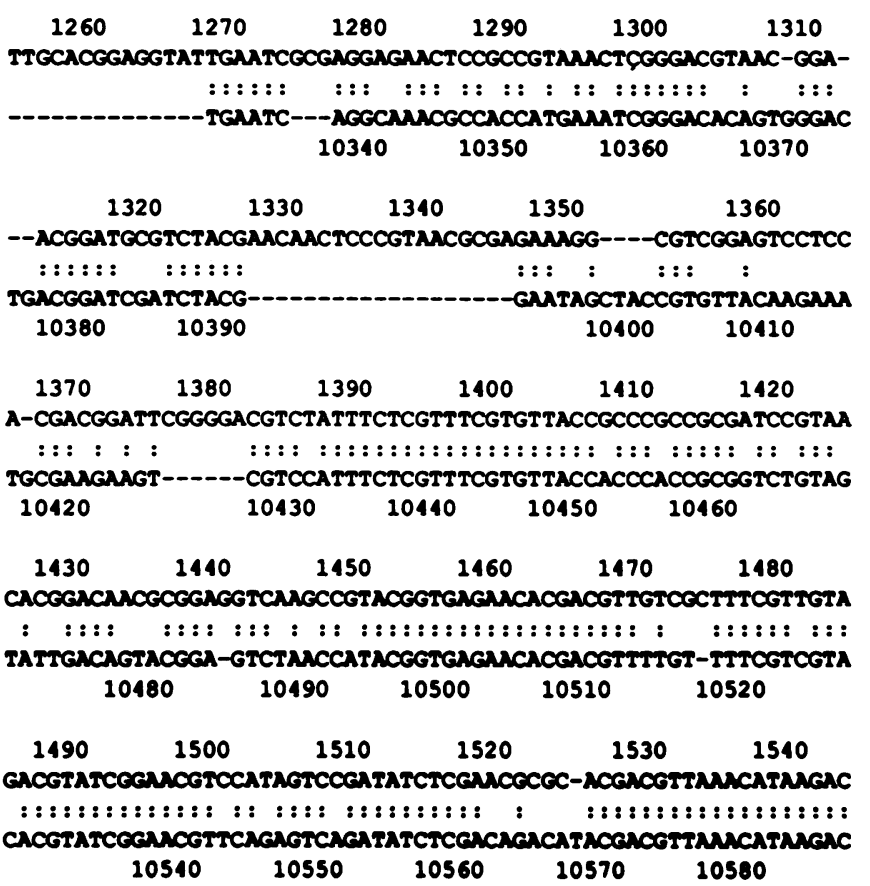

FIG. 6. DNA sequence homology between pSIC-9 and the SFV TIR. The 1.9-kb plasmid sequence from pSIC-9 (upper line) is displayed relative to the homologous 1.5-kb stretch of the SFV TIR (lower line). The SFV nucleotide numbers are from the terminus. The boxed triplet designates the putative initiator codons for the SFV ORF-T8 and the pSIC-9 ORF-2 (see Fig. 8).

restriction enzymes, including HindIII, SalI, and BamHI (not shown); thus, cloning experiments were done with the BamHI site of pUC8. Plasmids from cycloheximide-treated SIRC cells were purified as either OC or CCC species by preparative gel electrophoresis of DNA from Hirt supernatants, linearized with BamHI, and ligated to BamHI-digested pUC8. Transformation was performed into Escherichia coli JM83, and recombinant clones were screened with SFV BamHI E probe. All positive clones, however, were found to contain inserts smaller than the expected $4.8 \mathrm{~kb}$ representing the entire plasmid species, suggesting that at least some of the endogenous plasmid sequences are unstable in $E$. coli JM83. The clone with the largest insert ( $1.9 \mathrm{~kb})$, pSIC-9, was selected for sequence analysis. Control Southern blots, in

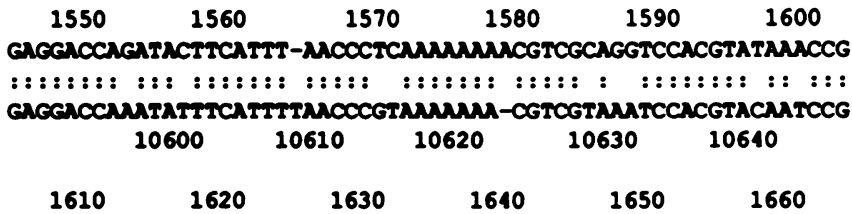

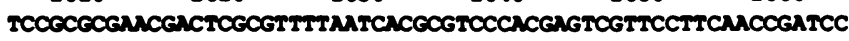

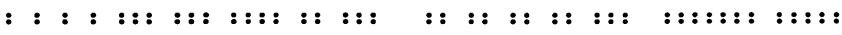
TтCACTCTACAMCTTECOTCTTEATCGTACGACCGACTAGACGTCGCTTCAMCTGATCC $\begin{array}{rrrrrr}10650 & 10660 & 10670 & 10680 & 10690 & 10700 \\ 1670 & 1680 & 1690 & 1700 & 1710 & 1720\end{array}$ AACGTGTCTTGCCTETAGTTCAGATAGTCCNAMGMATACACTCGTGTCCCTCGTATCCG

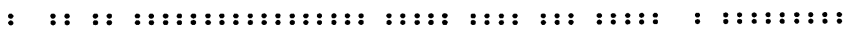
AGTGTATCATGCCTGTAGTTCAGATMATCCAMGAGNACACAGTCGTGATCTTCGTATCCG $\begin{array}{llllll}10710 & 10720 & 10730 & 10740 & 10750 & 10760\end{array}$

$\begin{array}{llllll}1730 & 1740 & 1750 & 1760 & 1770 & 1780\end{array}$
AGTAG COGGACTTTEMTATTCCGTCTTTMUATATACGATACCCTCGTGGACACTTCCC

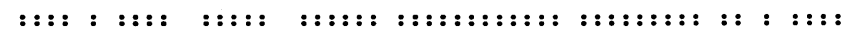
TETAGACTEACTCGGNATACACCGTCTCTMMATATACGACACCCTCGTGNACGC-TCCC $\begin{array}{llllll}10770 & 10780 & 10790 & 10800 & 10810 & 10820\end{array}$

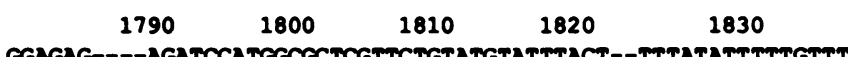

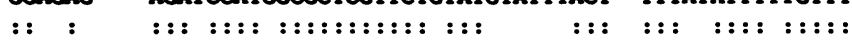
GGGCATMATAGACCCATAGCGCTCGTTCTATATAC----ACTTGTTTTMATTTATGTTT $\begin{array}{llllll}10830 & 10840 & 10850 & 10860 & 10870 & 10880\end{array}$

$\begin{array}{llllll}1840 & 1850 & 1860 & 1870 & 1880 & 1890\end{array}$

TTCCTCGGCCTGGGACGACTCGATGGTTTTATEACTGTCATT--TACGCCATTATGTATA : : : : : : : : : : : : : : : : : : : : : ::: : : ::::::::

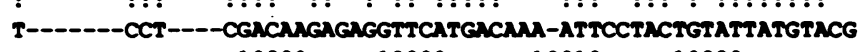
1900 cectrace ATGEATTT $\begin{array}{llll}10890 & 10900 & 10910 & 10920\end{array}$

(a)



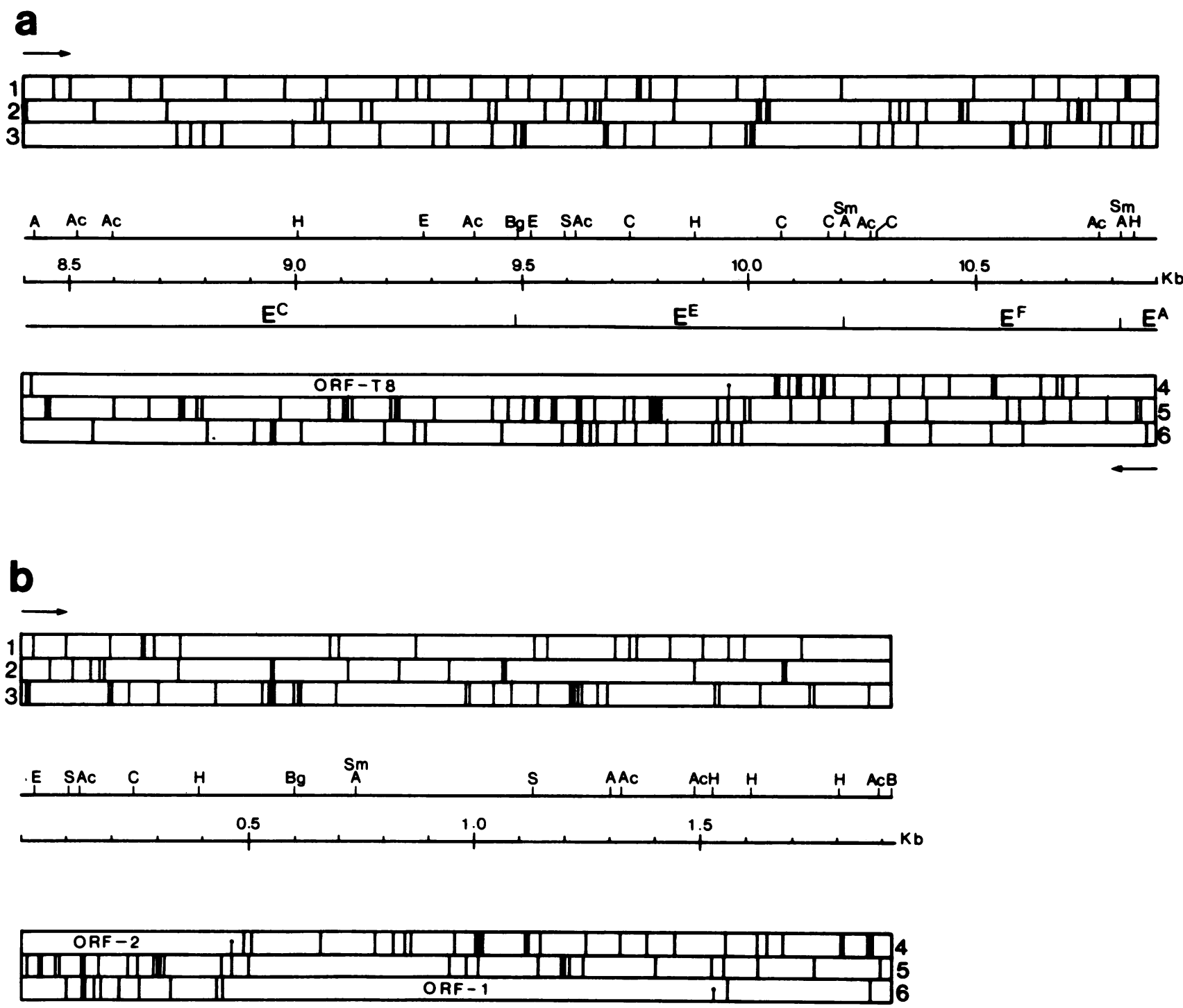

FIG. 7. Genomic organization of pSIC-9 and the homologous region of the SFV TIR. The six reading frames deduced from the DNA sequencing analysis of SFV TIR from 8.4 to $10.9 \mathrm{~kb}$ from the terminus (a) and pSIC-9 (b). Arrows refer to the direction of transcription. Restriction enzyme abbreviations are defined in the legend to Fig. 5. The first ATG codon ( ) in the designated open reading frames is indicated.

followed first by $0.39 \mathrm{~kb}$ of detectable sequence homology but with demonstrable divergence and then a large gap of $0.43 \mathrm{~kb}$ for which no pSIC-9-related sequences could be found in the SFV DNA. However, sequence homology reappeared at this point, and the remaining $0.63 \mathrm{~kb}$ of pSIC-9 sequences were extensively homologous to SFV sequences. If this region of the SFV TIR had been originally derived from the host rabbit cell via the pSIC-9 plasmid species, then these results suggest that (i) at least $0.46 \mathrm{~kb}$ has been highly conserved in the virus, (ii) $0.5 \mathrm{~kb}$ has been deleted, and (iii) almost $1 \mathrm{~kb}$ of pSIC-9-like sequences remains in the virus but has significantly diverged, although DNA cross-hybridization can still be detected.

Genomic organization of the rabbit plasmid and the homologous SFV sequences. To assess whether the highly conserved regions between pSIC-9 and SFV could be in biologically relevant regions, the open reading frames of the
pSIC-9 insert and the region of SFV between 8.4 and $10.9 \mathrm{~kb}$ from the viral terminus were diagrammed (Fig. 7). The viral sequence contained one long open reading frame, designated ORF-T8, in the strand which is transcribed towards the viral terminus (Fig. 7a). This is the only strand that was found to be transcribed efficiently (C. Macaulay and G. McFadden, manuscript in preparation), suggesting that ORF-T8 may, in fact, express a relevant viral protein. Note that the SFV reading frames from 9.49 to $9.95 \mathrm{~kb}$ are identical to those of the pSIC-9 sequences from 0 to $0.46 \mathrm{~kb}$ (Fig. 7B). It appears that the pSIC-9 clone was truncated in the cloning procedures at a point 157 amino acids from the $\mathrm{N}$ terminus of the putative conserved protein. Figure 8 illustrates the entire 514-amino acid sequence of the putative viral ORF-T8 protein, and the underlined region indicates this conserved 157-amino acid stretch at the $\mathbf{N}$ terminus of the plasmid ORF-2 protein. 


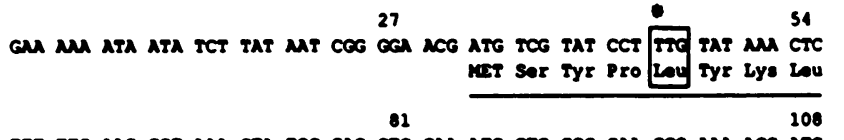

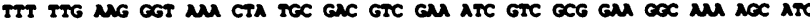
Phe lau bys Gly bys hau Cys Asp val Glu Ile val die Glu Gly Lys Ser Ile

135

CGA GCG CAT COE TTG GTG CTC TOC OCG TAT TCC MU TAC TTC TAC AOT CTG TTI

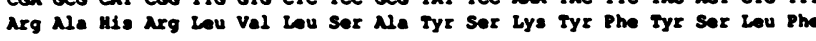
189

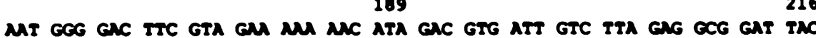
Aan Gly Aap phe val Glu lys Aan Ile Aap val Ile val hou Glu Ale Asp tyr 243

MU AOC GTA ITT GAT GTG ATT IAT TAC ATG TAC ACG GA TCG ATA GU TTA CAC Lys thr val phe Asp val Ile tyr tyr ket tyz thr Glu ser Ile Glu Lau H19 297 MU AOG MT MC GU TOC ATT ITC TCA TTG GCA CAC TAT CTA CAG ATT MC OCC Lyo Arg den den Glu Ser Ile Phe Ser bou Ale his tyr hou Gln Ile Aen Pro 351 378

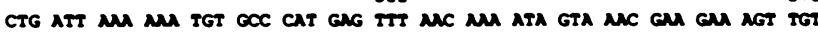
Leu Ile Lys Lys Cys Ne His Glu Pho Aon Lys Ile val Aan Glu Glu Ser Cys 105 ATA CAT CTG TTI MU TTC TCC GAG CTC IAC GAT CTG ACC GAG TTG MU COC AOG Ile H1s bou phe lys phe Ser Glu Leu tyr Asp bou thr Glu Leu Lys Arg Arg 459

ACC CEA TEG CTI ATG COC AGT ATG GTG ATG MT TCG AGA GAT CN CTA COG COE

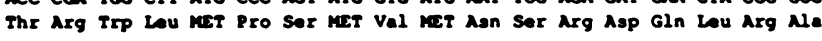

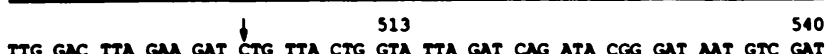
hau Aap bau Glu Aap bou beu lou val bou Aap gln Ile Arg Asp Asn val Asp $567 \quad 594$

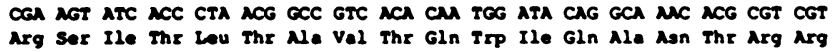
$621 \quad 648$ COT ATA COC TAC GCA GTA CM CTG GOG MU CGT ATT GGG GAC AGT CCC AGG ACT Arg Ile Arg tyr Ale val Gln heu Ale Lys Arg Ile Gly Asp Ser Pro Arg Thr

675 GTC TCA TOC MGA AOC GTG TAC MU CM TAT GTG ATG GM CTA CAG MT CAC CCT val ser ser asg thr val tyr lyo Gln tyr val ket Glu bou Glin Aan His Pro

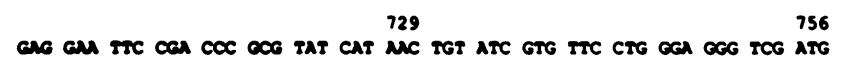

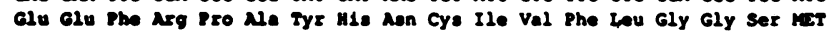

$$
703
$$

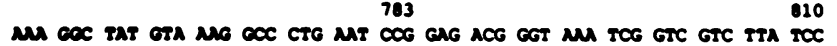

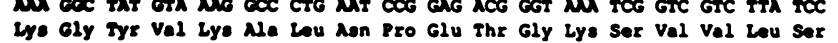

837

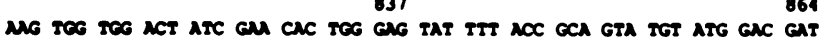
Lys Ixp Ixp the Ile Glu HI: Ixp Glu tyr Phe thr Nle val Cys iet Asp Aap

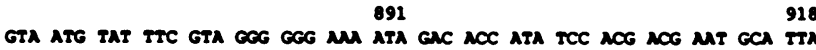

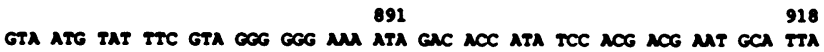
val het tyr phe val Gly Gly bys Ile Asp thr Ile Ser thr thr dan Ale beu 945

972

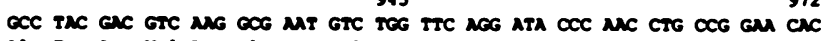
Ale tyr dap val lys dle den val ixp phe Arg Ile pro Aan hou Pro Glu his 999 1026

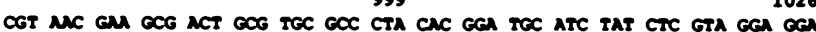
Asg Aan Glu Nle thr Ale Cys die Leu His Gly Cys Ile tyr heu val Gly Gly

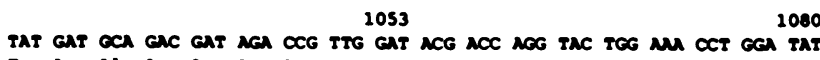
TAT GAT OCA GAC GAT ACA OCG TTG GAT ACG AOC 100 TAC TEG MU OCT OCA TAT Tyr Aap Als Aap Aap Arg Pro hou Aap the thr Asg tyr Itop byo Pro Gly Tyr

1107 1134 GAT COG TEG TAC NAG OGA OCC ACC CTG GTG GM COC GTT GOC CU ACG AOT ФOC Aap Arg Irp tyr hys Gly Pro thr hau val Glu pro val ale Glu thr ser dle

$$
1161
$$

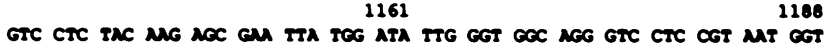
val bou tyr Lys Ser Glu beu Trp Ile Lau Gly Gly Arg Val hau Axg Asn Gly

$$
2215
$$

1242

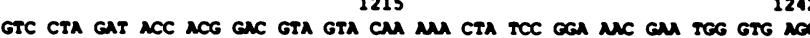
val Leu Asp thr thr Asp val val Gln lys Leu Ser Gly Asn Glu Irp val Asg

$$
1269
$$

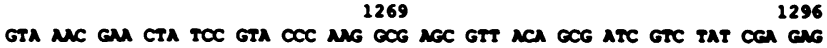
val asn Glu beu Ser val pro bys die ser val thr dia Ile val tyr arg Glu

$$
1323
$$

1350

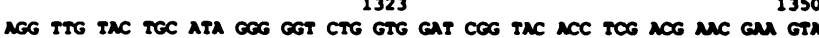
Arg beu Tyr Cyo Ile Gly Gly hau val Aop Arg Tyr thr ser thr Aan Glu val

$$
1377
$$

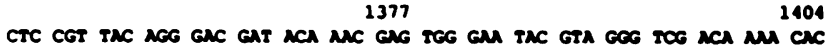
Leu Arg Tyr Arg Aap Aap thr Asn Glu Ixp Glu tyr val Gly Ser thr Lys His

$$
1431
$$

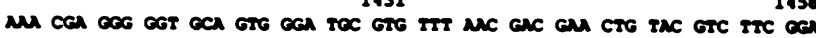
Lys Arg Gly Gly dla val Gly Cys Val Phe dan dap Glu hou tyr val phe Gly

$$
1405
$$

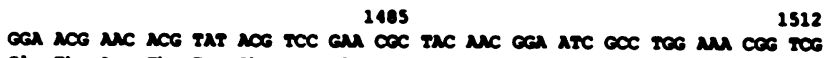
Gly thr den the Tyr thr sar Glu Arg tyr Aan Gly Ile Ale Trp Lye Arg sar

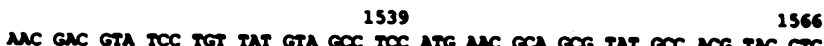
Aan dap Val ser Cys tyr val die ser wet den dle Mle tyr die thr tyr bev

1593

GAG TTG TAN ACT GTT ITT ATT ACT CUN MCA GTA ATA G Glu Leu.

FIG. 8. Comparison of the deduced SFV ORF-T8 amino acid sequence with the pSIC-9 ORF-2 sequence. The SFV nucleotide sequence encompassing the viral ORF-T8 sequence is displayed. Nucleotide 1 here corresponds to nucleotide 9989 of Fig. 6, and the displayed sequence extends to nucleotide 8406. The underlined region corresponds to the area of identity with the pSIC-9 ORF-2 amino acid sequence. The box with the asterisk contains the single-nucleotide difference (SFV nucleotide 9947) between ORF-T8 and ORF-2, although the amino acid (leucine) is unchanged. The arrow indicates the breakpoint for the cloned pSIC-9 sequence.

A second long major open reading frame, designated ORF-1, was detected in pSIC-9 (Fig. 7) but had no counterpart in the virus because of the previously mentioned $0.5-\mathrm{kb}$ deletion and the pronounced sequence divergence in this region between the plasmid and the virus. ORF-1 potentially encodes for a 361-amino acid protein which may once have been acquired by SFV but has now been discarded from the virus genome as a functional genetic entity.

To determine whether any of the nucleotide or putative protein sequences determined here have any counterparts in the current databases, homology searches were carried out with the available GenBank (National Institutes of Health) nucleotide and NBRF protein data bases. These searches revealed that the SFV and rabbit plasmid sequences were unrelated to any other known plasmid or viral sequences, thereby arguing against a close relationship between pSIC-9 sequences and any of the commonly known infectious agents. However, one interesting homology involving the pSIC-9 ORF-1 amino acid sequence was highlighted during the data base analysis. A series of mammalian protease inhibitors, including $\alpha 1$-antichymotrypsin (Fig. 9), $\alpha 1$ antitrypsin, and antithrombin III, were found to display significant homology with the putative ORF-1 protein. In the important region from amino acids 367 to 399 of the $\alpha 1$ antichymotrypsin precursor, which contains the reactive site (underlined in Fig. 9), 18 of the 33 amino acids were identical. This compares favorably with the values of 11 of 33 for $\alpha 1$-antitrypsin versus $\alpha 1$-antichymotrypsin and 18 of 33 for antithrombin III versus $\alpha 1$-antichymotrypsin (9). While these data do not prove that the putative pSIC-9 ORF-1 protein is a serine protease inhibitor, they do suggest that the plasmid sequences described here are, in fact, bona fide cellular sequences derived from uninfected rabbit cells. The organization of these rabbit ORF-1 and ORF-2 se- 


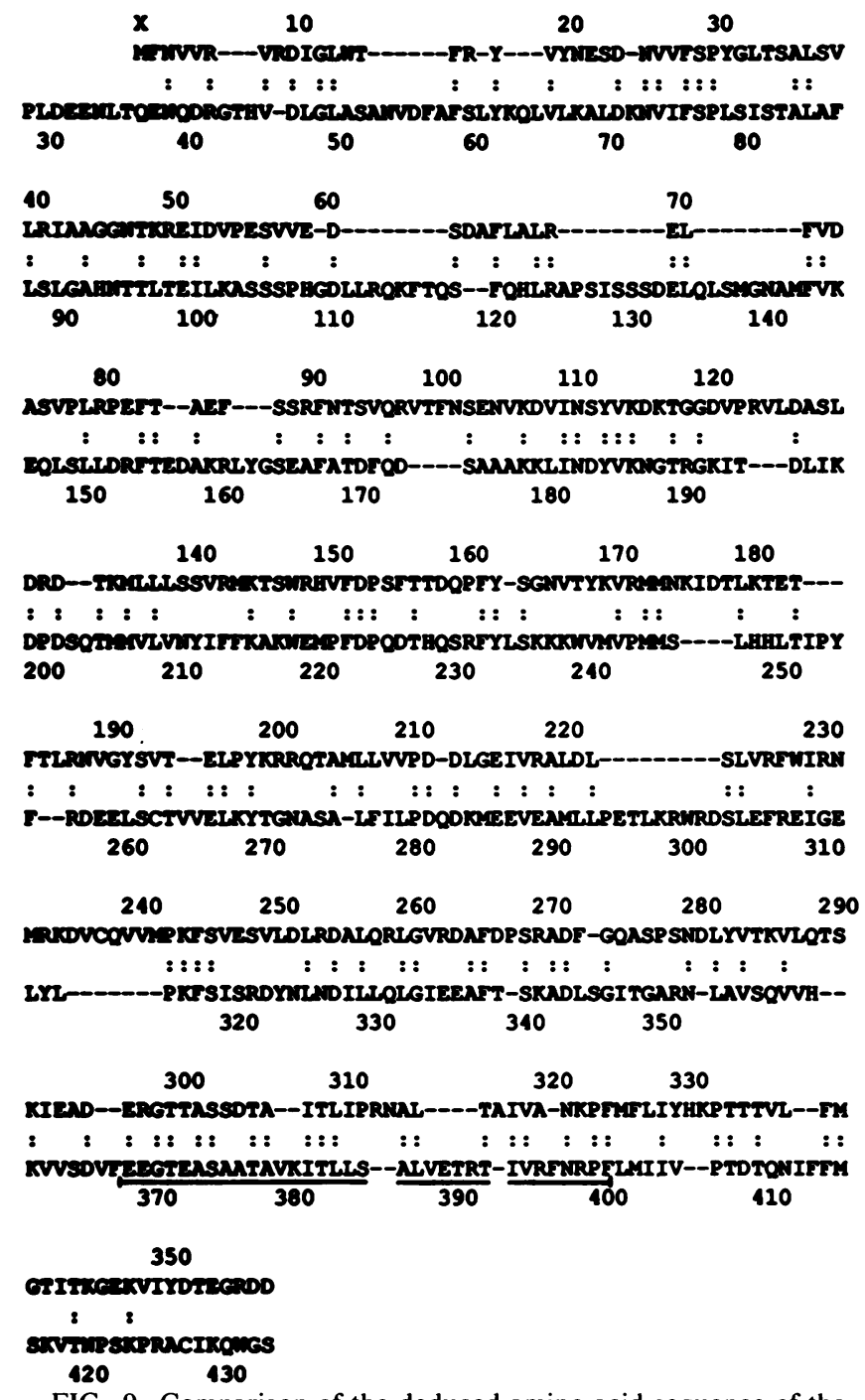

FIG. 9. Comparison of the deduced amino acid sequence of the rabbit plasmid ORF-1 with that of human $\alpha 1$-antichymotrypsin. The published sequence of human $\alpha 1$-antichymotrypsin (9) is displayed below the deduced sequence of pSIC-9 ORF-1. The underlined region represents the region flanking the $\alpha 1$-antichymotrypsin active site.

quences with respect to the rabbit genome, as well as the more general question of how they came to reside within CCC DNA molecules, is currently being investigated.

\section{DISCUSSION}

Although first detected in HeLa cells more than a decade ago (35), the presence of spc DNA in a broad variety of mammalian cells has become a widely documented but poorly understood phenomenon. The copy number of these plasmid-like DNA species can vary enormously from cell type to cell type and can be markedly influenced by such factors as growth rate, state of differentiation, or aging in culture. They have been detected in a variety of cell lines, including $D$. melanogaster $(36,38), \mathrm{HeLa}(20,35)$, Chinese hamster ovary $(37)$, and monkey $(3,32)$ cells, and also in a number of tissues $(8,12)$. Frequently, more than $100 \mathrm{spc}$ DNA molecules per cell have been detected (35), but the copy number of an individual spc DNA can vary widely; values of under 0.1 per cell have been reported (37). The function, if any, of these molecules in eucaryotic cells is unknown, but pertinent to this discussion is the fact that there is evidence that at least some of these plasmid species can at times have a cytoplasmic location $(35,37)$. Therefore, it is possible to rationalize how a poxvirus such as SFV, which replicates exclusively in the cell cytoplasm, could encounter and recombine with such extrachromosomal host sequences. The recent demonstration that at least two vaccinia virus polypeptides, thymidine kinase and a 19,000molecular-weight early gene product, appear to be related to host polypeptides $(5,6,22)$ may, in fact, be a reflection of a more generalized mechanism by which poxviruses can acquire host sequences.

In this paper, we have shown that DNA probes from a limited 2- to 3-kb region of the SFV TIR region crosshybridized with a novel endogenous plasmid-like DNA species detected in uninfected rabbit cells. This extrachromosomal DNA species was shown to be amplified 20- to 50 -fold by treatment of the cells with cycloheximide and could be detected predominantly as CCC molecules, consistent with observations made for spc DNA in other eucaryotic cells. A cloned 1.9-kb fragment of the rabbit plasmid from SIRC cells was sequenced and compared with the homologous $2.5-\mathrm{kb}$ region of the SFV genome. Interestingly, one of the two plasmid open reading frames, ORF-2, was identical to the analogous stretch of one SFV open reading frame, ORF-T8. If the first methionine codon was utilized as an initiator in each case, then the $\mathrm{N}$-terminal 157 amino acids of the putative 514 residue SFV protein would be identical to the N-terminal 157 amino acids encoded in the plasmid ORF-2, suggesting that the encoded protein was conserved by the virus. On the other hand, a second plasmid open reading frame, ORF-1, diverged considerably in the viral genome and no longer exists in SFV as a defined reading frame, although significant DNA sequence homology was still in evidence. Data base analysis revealed that the putative plasmid ORF-1 protein is closely related to a series of proteins from the serine protease inhibitor superfamily. For example, 135 of the 361 amino acids of the putative ORF-1 gene product are identical to the published human $\alpha 1$ antichymotrypsin sequence (9). Although the origin and function of the rabbit plasmid sequences remain to be determined, it is intriguing that the genes for serine protease inhibitors, at least as determined to date (e.g., see reference 23), contain multiple intervening sequences, and yet the rabbit plasmid ORF-1 represents a single continuous 361amino acid sequence. The possibility that the rabbit plasmid species described here may have been originally generated by reverse transcription of rabbit mRNA into CCC DNA molecules will be more readily assessed once the genomic organization of these putative rabbit genes is determined.

The localization of this plasmid homology within 2 to $3 \mathrm{~kb}$ of the SFV inverted repeats closest to the unique internal sequences has significance for another reason. Recently Strayer et al. (39) isolated a novel tumorigenic poxvirus of rabbits, designated malignant rabbit virus (MRV), which possesses a number of biological features reminiscent of both SFV and myxoma virus, which is a related leporipoxvirus of rabbits and the agent of myxomatosis. Of particular interest is the fact that MRV induces, at early times of infection, fibromas in rabbits that are indistinguishable from those of SFV, but later these tumors spread throughout the body of the rabbit with an invasive profile similar to that of the lesions of myxomatosis (39). The 
genomic structure of MRV DNA indicates that this virus is indeed a bona fide recombinant between SFV and myxoma virus and that the only difference between MRV and myxoma virus is the replacement of 4 to $6 \mathrm{~kb}$ of myxoma sequences with a SFV DNA sequence of equivalent size (4). This 4 to $6 \mathrm{~kb}$ of SFV DNA inserted into the myxoma genome is derived from the SFV terminal repeat region closest to the unique internal sequences (4). Thus, the stretch of DNA that we identified in the SFV TIR which is homologous to the endogenous cellular plasmid species is a subset of those sequences donated by SFV to the myxoma virus genome in the creation of the recombinant MRV. In fact, the SFV ORF-T8, which is identical in sequence to the truncated pSIC-9 ORF-2, has been transferred in toto to MRV and provides suggestive evidence that it may play a critical role in SFV tumorigenesis.

Regardless of the precise genetic function of the SFV sequences mapped in this paper, it seems likely that endogenous cellular plasmids can mediate the transposition of biologically important genes. Further analysis of the origin of these plasmids may not only reveal how cytoplasmically replicating viruses such as poxviruses can acquire cellular genes but also shed light on the origin of tumorigenic poxviruses in general.

\section{ACKNOWLEDGMENTS}

This work was supported by the Alberta Heritage Foundation for Medical Research (AHFMR) and the National Cancer Institute of Canada. Computer costs of the BIONET resource were funded by Public Health Service grant 1-441-RR01685-01 from the National Institutes of Health. G.M. is an AHFMR scholar, and C.U. is an AHFMR postdoctoral fellow.

We are grateful to $M$. J. Lawler for assistance with the data base analyses; to A. R. Morgan and J. Colter for proofreading the manuscript; to F. Bugeja, A. Wills, and R. Maranchuk for technical assistance; and to D. Oare and P. Knight for preparation of the manuscript.

\section{LITERATURE CITED}

1. Archard, L. C., M. Mackett, D. E. Barnes, and K. R. Dumbell. 1984. The genome structure of cowpox white pock variants. J. Gen. Virol. 65:875-886.

2. Bearcroft, W. C. G., and M. F. Jamieson. 1958. An outbreak of subcutaneous tumors in rhesus monkeys. Nature (London) 182:195-196.

3. Bertelsen, A. H., M. Z. Humayun, S. G. Karfopoulos, and M. G. Rush. 1982. Molecular characterization of small polydisperse circular deoxyribonucleic acid from an African green monkey cell line. Biochemistry 21:2076-2085.

4. Block, W., C. Upton, and G. McFadden. 1985. Tumorigenic poxviruses: genomic organization of malignant rabbit virus, a recombinant between Shope fibroma virus and myxoma virus. Virology 140:113-124

5. Blomquist, M. C., L. T. Hunt, and W. C. Barker. 1984. Vaccinia virus $19 \mathrm{~K}$ protein: relationship to several mammalian proteins, including two growth factors. Proc. Natl. Acad. Sci. USA 81:7363-7367.

6. Brown, J. P., D. R. Twardzik, H. Marquardt, and G. J. Todaro. 1985. Vaccinia virus encodes a polypeptide homologous to epidermal growth factor and transforming growth factor. Nature (London) 313:491-492.

7. Cabirac, G. F., D. S. Strayer, S. Sell, and J. L. Leibowitz. 1985. Characterization, molecular cloning, and physical mapping of the Shope fibroma virus genome. Virology 143:163-170.

8. Calabretta, B., D. L. Robberson, Barrera-Saldana, T. P. Lambrou, and G. F. Saunders. 1982. Genome instability in a region of human DNA enriched in Alu repeat sequences. Nature (London) 296:219-225.
9. Chandra, T., R. Stackhouse, V. J. Kidd, K. J. H. Robson, and S. L. C. Woo. 1983. Sequence homology between human $\alpha 1$ antichymotrypsin, $\alpha$ l-antitrypsin and antithrombin III. Biochemistry 22:5055-5061.

10. Dales, S., and B. G. T. Pogo. 1982. The biology of poxviruses. Springer-Verlag, New York.

11. Delange, A. M., C. Macaulay, W. Block, T. Mueller, and G. McFadden. 1984. Tumorigenic poxviruses: construction of the composite physical map of the Shope fibroma virus genome. J. Virol. 50:408-416.

12. Delap, R. J., and M. G. Rush. 1978. Change in quantity and size distribution of small circular DNAs during development of chicken bursa. Proc. Natl. Acad. Sci. USA 75:5855-5859.

13. Dumbell, K. R., and L. C. Archard. 1980. Comparison of white pock (h) mutants of monkeypox virus with parental monkeypox and with variola-like viruses isolated from animals. Nature (London) 286:29-32.

14. Esposito, J. J., C. D. Cabradilla, J. H. Nakano, and J. F. Obijeski. 1981. Intragenomic sequence transposition in monkey poxvirus. Virology 109:231-243.

15. Febvre, H. 1962. The Shope fibroma virus of rabbits, p. 79-111. In A. J. Dalton and F. Haguenau (ed.), Tumors induced by viruses: ultrastructural studies. Academic Press, Inc., New York.

16. Henikoff, S. 1984. Unidirectional digestion with exonuclease III creates targeted breakpoints for DNA sequencing. Gene 28:351-359.

17. Hirt, B. 1967. Selective extraction of polyoma DNA from infected mouse cell cultures. J. Mol. Biol. 26:365-369.

18. Holowczak, J. A. 1982. Poxvirus DNA. Curr. Top. Microbiol. Immunol. 97:27-79.

19. Jacquemont, B., M. Richard, and J. Grange. 1971. Failure to detect homology between the DNA of the Shope fibroma virus and the DNA of the sensitive cell. J. Gen. Virology. 10:237-242.

20. Jones, R. S., and S. S. Potter. 1985. L1 sequences in HeLa extrachromosomal circular DNA: evidence for circularization by homologous recombination. Proc. Natl. Acad. Sci. USA 82:1989-1993.

21. Jones, T. R., and R. W. Hyman. 1983. Specious hybridization between herpes simplex virus DNA and human cellular DNA. Virology 131:556-560.

22. Kwoh, T. J., and A. Engles. 1984. The nucleotide sequence of chicken thymidine kinase and the relationship of its predicted polypeptide to that of the vaccinia virus thymidine kinase. Nucleic Acids Res. 12:3959-3971.

23. Long, G. L., T. Chandra, S. L. C. Woo, E. W. Davie, and K. Kurachi. 1984. Complete sequence of the cDNA for human $\alpha 1$-antitrypsin and the gene for the $\mathrm{S}$ variant. Biochemistry 23:4828-4837.

24. McFadden, G., and S. Dales. 1979. Biogenesis of poxviruses: mirror image deletions in vaccinia virus DNA. Cell 18:101-108.

25. McFadden, G., and S. Dales. 1982. Organization and replication of poxvirus DNA, p. 173-190. In A. S. Kaplan (ed.), Organization and replication of viral DNA. CRC Press, Inc., Boca Raton, Fla.

25a.Moss, B. 1985. Replication of poxviruses, p. 685-703. In B. N. Fields (ed.), Virology. Raven Press, New York.

26. Moyer, R. W., R. L. Graves, and C. T. Rothe. 1980. The white pock $(\mu)$ mutants of rabbit poxvirus III. Terminal DNA sequence duplication and transposition in rabbit poxvirus. Cell 22:545-553.

27. Peden, K., P. Mounts, and G. S. Hayward. 1982. Homology between mammalian cell DNA sequences and human herpes virus genomes detected by a hybridization procedure with high-complexity probe. Cell 31:71-80.

28. Postlethwaite, R. 1970. Molluscum contagiosum: a review. Arch. Environ. Health 21:432-452.

29. Puga, A., E. M. Cantin, and A. L. Notkins. 1982. Homology between murine and human cellular DNA sequences and the terminal repetition of the $S$ component of herpes simplex virus type 1 DNA. Cell 31:81-87.

30. Rüdiger, R., G. W. Bornkamm, and B. Fleckenstein. 1984. Human cytomegalovirus DNA sequences with homologies to 
the cellular genome. J. Gen. Virology. 65:1351-1364.

31. Sanger, F., S. Nicklen, and A. R. Coulson. 1977. DNA sequencing with chain-terminating inhibitors. Proc. Natl. Acad. Sci. USA 74:5463-5467.

32. Schindler, C. W., and M. G. Rush. 1985. The KpnI family of long interspersed nucleotide sequences is present on discrete sizes of circular DNA in monkey (BSC-1) cells. J. Mol. Biol. 181:161-173.

33. Shmookler Reis, R. J., C. K. Lumpkin, Jr., J. R. McGill, K. T. Riabowol, and S. Goldstein. 1985. Amplification of inter-Alu extrachromosomal DNA during cellular aging: retraction and explanation. Nature (London) 316:167.

34. Shope, R. E. 1932. A transmissible tumor-like condition in rabbits. J. Exp. Med. 56:793-802.

35. Smith, C. A., and J. Vinograd. 1972. Small polydisperse circular DNA of Hela cells. J. Mol. Biol. 69:163-178.

36. Stanfield, S. W., and D. R. Helinski. 1976. Small circular DNA in Drosophila melanogaster. Cell 9:333-345.

37. Stanfield, S. W., and D. R. Helinski. 1984. Cloning and characterization of small circular DNA from Chinese hamster ovary cells. Mol. Cell. Biol. 4:173-180.

38. Stanfield, S. W., and J. A. Lengyel. 1979. Small circular DNA of Drosophila melanogaster: chromosomal homology and kinetic complexity. Proc. Natl. Acad. Sci. USA 76:6142-6146.

39. Strayer, D. S., E. Skaletsky, G. F. Cabirac, P. A. Sharp, L. B. Corbeil, S. Sell, and J. L. Liebowitz. 1983. Malignant rabbit fibroma virus causes secondary immunosuppression in rabbits. J. Immunol. 130:399-404.

40. Szybalski, W., H. Kubinski, Z. Hradecna, and W. Summers. 1971. Analytical and preparative separation of the complementary DNA strands. Methods Enzymol. 21:383-413.

41. Viera, J., and J. Messing. 1982. The pUC plasmids and M13 $\mathrm{mp} 7$-derived system for insertional mutagenesis and sequencing with universal primers. Gene 19:259-268.

42. Wills, A., A. M. Delange, C. Gregson, C. Macaulay, and G. McFadden. 1983. Physical characterization and molecular cloning of the Shope fibroma virus DNA genome. Virology 130:403-414.

43. Wittek, R. 1982. Organization and expression of the poxvirus genome. Experientia 38:285-310. 